INTERNATIONAL JOURNAL OF MULTidisciplinARY RESEARCH AND ANALYSis

ISSN(print): 2643-9840, ISSN(online): 2643-9875

Volume 05 Issue 01 January 2022

DOI: 10.47191/ijmra/v5-i1-13, Impact Factor: 6.072

Page No.- 87-94

\title{
Brand Image and Supply Chain Performance of Automobile Marketing Firms in Rivers State of Nigeria
}

\author{
Ikegwuru Mac-Kingsley (PhD)
}

Department of Marketing Rivers State University, Port Harcourt, Nigeria.

\begin{abstract}
This study examined the influence of brand image on supply chain performance of automobile marketing firms in Rivers State of Nigeria. The population for the study was sixty-eight (68) automobile marketing firms in Rivers State, whose wholesome list was acquired from the business unit of the Rivers State Ministry of Commerce and Industry as at October, 2020. A causal thought-out analytical model was inculcated to grasp the two hypotheses poised for the study. To arrive at the sample size for the study, the Taro Yamane's formula for determining sample size was used. The simple random technique of probability sampling was utilized to select 40 firms from the sample and the respondents for the study were verified by contacting four managers from each of the 40 automobile marketing firms under study. The number of respondents contacted was: 40 multiplied by 6 , which gives 240 respondents. A 5 -point likert-scaled questionnaire was administered to respondents. The accurate questionnaire sent out were 240 , from which 215 responses were received, and after establishing the validity of the questions 200 (93\%) The 200 questionnaires generated the useful response rate. The analysis was made up of descriptive and inferential statistics with SPSS version 22 providing aid. The inferential statistics involved three parametric inferential testsPearson's Product Moment Coefficient (PPMC), One Way Analysis of Variance (ANOVA) and Simple Regression Analysis. The PPMC was used to test the relationship between the variables, ANOVA was employed to test the differences in means of responses on the variables, while by means of the simple regressions, the study tested the effect of the elements of brand image on supply chain performance. The results demonstrated that brand identity has a strong, positive and significant influence on supply chain performance, and brand personality has a moderate, positive and significant influence on supply chain performance. Therefore, the study concludes that brand image significantly influences supply chain performance of automobile marketing firms in Rivers State, and recommends that, managers of automobile marketing firms should design brand image enhancing programs that are competent in bringing about positive supply chain performance in order to survive in the highly competitive and dynamic business landscape.
\end{abstract}

KEY WORDS: Brand identity, Brand image, Brand personality, Supply chain performance.

\section{INTRODUCTION}

Brand image has pulled off an elemental enormity in the contemporary market and is in use as a resource of setting vigorous knots with customers, capable of prompting brand loyalty, generating healthier profitability, cost-effectiveness and sustainability for companies (Drennan et al., 2015; Hegner, Fenko \& Teravest, 2017), and in recent times, most automobile marketing firms are generating brand image to appeal to a wide range of customers. Accordingly, firms have instigated reasonably, a lot of subtle brand basics, as the pursuit for an improved perceptiveness of brand image scenery in the market through a fitting position, which is cultivated by customers in association with a precise brand (Maehle \& Shneor, 2010; Zainol, Omar, Osman \& Habidin, 2010).

Asim Nasar et al. (2012) affirm that emerging businesses worldwide have the ubiquitous aspiration of growing their brand image since lots of companies are facing strong brand war in the midst of competitors to attain supreme market share. A company can gain supreme market share by means of offering unparalleled product/brand anchored on levelheaded price. It is therefore through providing most first-rate eminent brand image by means of apposite and suitable brand positioning that companies can gain a positive marketing performance.

Numerous studies have been hoisted to spot the connections between brand image and performance ( Koll \&von Wallpach 2014, Trump 2014, Hollebeek et al., 2014), however none studied these concepts using simultaneously the dimensions and 


\section{Brand Image and Supply Chain Performance of Automobile Marketing Firms in Rivers State of Nigeria}

measures adopted in this present study. This study therefore, investigates the effect of brand image on marketing performance of automobile marketing firms in Rivers State of Nigeria.

\section{STATEMENT OF THE PROBLEM}

It is clear as crystal that strict competition exists in Nigerian automobile marketing firms; thus making surviving in such competitive environment necessitates the implementation of confident marketing strategies as well as brand image. Automobile marketing firms cannot say for certain, the kind of impact, brand image has on their marketing performance. Besides, there exists a dearth of academic investigation on the subject matter, in Rivers State, Nigeria. This study therefore, investigates the influence of brand image on marketing performance of automobile marketing firms in Port Harcourt.

\section{RESEARCH QUESTIONS}

From the study objectives, the following research questions were formulated:

1. To what extent does brand identity relate with supply chain performance?

2. To what extent does brand personality relate with supply chain performance?

\section{LITERATURE REVIEW AND HYPOTHESES}

\section{Concept of Brand Image}

According to Kotler and Armstrong (2008), a brand is a module in an organization's attachment with its customers as it shapes consumers' perception concerning a product and the entire thing that the product symbolizes to the consumer. A brand as a name, term, sign, symbol or their combinations employed in distinguishing and differentiating a company's products from those of competitors (Okpara, 2012).Brand image is the contemporary outlook of the customers in relation to a brand. It is therefore, a unique bunch of linkages contained by the minds of target customers. Brand image presages what the brand at the split second symbolizes, constituting a deposit of beliefs held about an explicit brand. This study in collaboration with Bambong, Sukina \& Wajaya (2015) adopts brand identity and brand personality as the dimensions of brand image.

\section{Brand Identity}

Brand identity takes account of all that makes a brand sweeping and exclusive, and depicts how accompany portrays itself to the customers. McCommet and Cogan (2004) noted that strong brands put forward a lucid brand identity that is well discrete and explicate, supplying a formation for the incorporation of the brand (Aaker, 2002). A strapping brand should have a coherent and inestimable identity; if it doesn't, this may necessitate that the brand craves to be modified or extended. Therefore, brand identity constitutes of an exclusive deposit of brand associations that a firm labours to put up in the market. These associations divulge what the brand is and its connected promises to the customers. Brand identity is in real meaning what firms would like their brand to be, connote or symbolize. In an exceptionally uncomplicated logic, brand identity is the quintessence and dependability of any brand. Hence, it is habitually professed or observed as the image a firm transmits concerning its product or its product grouping.

\section{Brand Personality}

Brand personality is a concept contained by the field of relational marketing was first coined by Azoulay and Kapferer (2003). Brand personality is defined as a situate of human uniqueness linked to a brand (Aaker, 1997). Brand personality portrays the inner distinctiveness of a brand (Yeoh et al., 2014).

It is in no misgiving that brand personality illustrates a brand as having corresponding individuality as a person and to underpin this fact, Aaker (1997) speculates that brand personality is the set of human individuality with a specified brand. Brand personality identifies how a firm relates a brand with human personality qualities for the purpose of generating a symbolic association that is physically powerful, exclusive, distinct and steadfast to the consumer (Frelings \& Forbes, 2005). Hence, as an eye-catching and conspicuous concept of marketing is very necessary for grasping all of the company's objectives, which result in trustworthiness, fulfillment and profitability? The concept of brand personality offers a major managerial advantage. It helps better understand the development and sustaining of relations between brands and consumers (Gouteron, 2008). Brand personality involves the affective, emotional and dynamic facets of a brand (Azoulay \& Kapferer 2003).

\section{The Concept of Supply Chain Performance}

The term performance is expressed as an idea in contemporary business that has put up with predicaments associated with revealing its concepts in a number of quarters (Hefferman \& Flood, 2000).Performance is sometimes substituted with 


\section{Brand Image and Supply Chain Performance of Automobile Marketing Firms in Rivers State of Nigeria}

productivity, however Ricardo (2001) points out that there was dissimilarity between productivity and performance, productivity being a ratio standing for the quantity of work completed in a specified time frame.

Maestrini, Luzzini, Maccarrone and Caniato (2017) defined performance as "A set of metrics used to compute the proficiency and efficacy of supply chain processes and interactions, traversing several organizational functions and numerous firms and empowering supply chain instrumentation. Previously performance was measured by cost with the passage of time more financial indicators were added like return on asset, return on investment, sale and etc. (Anand \& Grover, 2015). Only financial indicators are not enough for measure overall and accurate performance, consequently, with the intent of balance scorecard approach some operational indicators were added (Attia, 2015; Shahbaz, Rasi, Zulfakar, Bin \& Asad, 2018). Other approaches also added values in measuring supply chain like quantitative or qualitative measures, strategic, tactical and operational measures and etc. (Arzu-Akyuz \& Erman-Erkan, 2010). A comprehensive review revealed that for the good performance measure, all the performance measure should consider both financial and non-financial items, all the levels of supply chain must be considered and all process of supply chain should be included so the performance should be measured by operational performance (Shahbaz, Rasi, Zulfakar, Bin, Abbas \& Mubarak, 2018).

Indicators to measure above mentioned performance are alike. Supply chain performance had been measured by operational performance and its indicators were quality performance, flexibility performance, customer service, delivery performance and cost performance (Kauppi et al., 2016). Effendi (2015) has use logistic effect for SCM and its metric consisted in order fill rate, order fulfillment lead time, operations flexibility, inventory turnover, and total logistics cost.

\section{Empirical Review}

Eduardo de Paula eSilva Chaves (2017) investigated the associations amid brand identity, positioning, brand image and brand equity using a qualitative-quantitative research, and an exploratory-descriptive study. The method employed envelops a case study, a qualitative and quantitative descriptive research. The data was analyzed by means of the regression method, and the findings reveal that there is a significant association between brand identity, positioning, brand image and brand equity.

Kamran and Farzaneh (2017) investigated the influence of consumers' perception of brand personality on purchase intention of Maz Maz Company in Tehran by means of structural modeling and a causal-comparative technique. In addition, the study used library and field research techniques with a questionnaire to accumulate data from the consumers. The study's sample size was arrived at by means of Cochran's formula, while the Cronbach's alpha was used to test the validity of the study. The correlation analysis and structural modeling anchored on SPSS and AMOS software programs. The study disclosed that there is a positive and significant influence of consumers' perception of brand personality on purchase intention.

Ogbuji, Onuoha and Owhorchukwu (2016) explored brand personality and marketing performance of deposit money banks in Port Harcourt by means of the survey method. The analysis was handled with the Spearman rank correlation coefficient with the aid of SPSS version 21.0, and the study found that there is a strong and positive relationship between brand personality and marketing performance of deposit money banks in Port Harcourt.

Ibok and Etuk (2015) studied the association between brand identity and customers' loyalty in the Nigeria telecommunication industry, using mixed sampling method. Data for the study were arrived atby means of a survey of 207 customers extracted from four major telecommunication companies in Akwa Ibom State. Data analysis was conducted using descriptive and inferential statistics, the regression and correlation analysis. The study found that a strong positive and significant relationship exist between brand identity and customers' loyalty.

Muhammad Shoaib et al. (2012) exposed the relationships between brand image, advertisement and purchase behavior by selecting 185 family members from diverse areas. The study discovered an association between advertisements of multinational products and consumer purchasing behavior. 
Based on the review above, the following operational framework was designed:

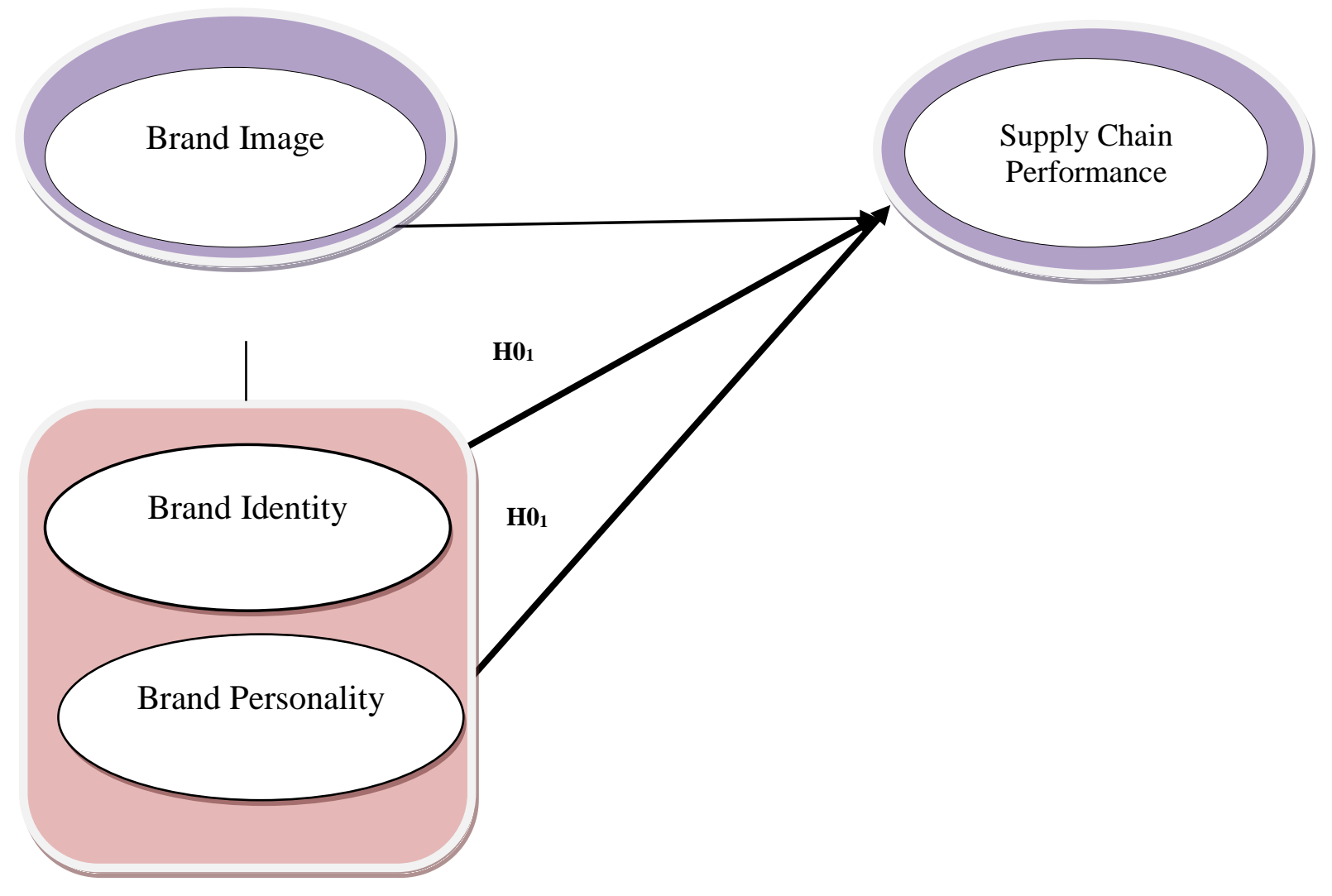

Figure 1: Operational Framework of Brand Image and Supply Chain Performance.

Sources: Bambong, Sukina and Wajaya (2015) and Harcourt and Ikegwuru, (2018).

Based on the review of literature and in line with the framework provided by the review of literature, the following research hypotheses were tested at 0.05 level of significance to show cautious association between the criterion and predictor variables:

Ho1: Brand identity does not significantly influence supply chain performance of automobile marketing firms of Rivers State of Nigeria. .

Ho2: Brand personality does not significantly influence supply chain performance of automobile marketing firms of Rivers State of Nigeria.

\section{RESEARCH METHODOLOGY}

The population for the study was sixty-eight (68) automobile marketing firms in Rivers State, whose wholesome list was acquired from the business unit of the Rivers State Ministry of Commerce and Industry as at October, 2020. A causal thoughtout analytical model was inculcated to grasp the two hypotheses poised for the study. To arrive at the sample size for the study, the Taro Yamane's formula for determining sample size was used.

Thus the formulae $n=N / 1+N$ (c) squared

Where $\mathrm{n}$ is the sample size

$\mathrm{N}$ is the population

1 is constant and

e is level of significance (i.e. 0.05).

Therefore; $n=68 / 1+68(0.05) 2$

$$
\begin{aligned}
& n=68 / 1+68(0.0025)=68 / 1+0.6775 \\
& n=68 / 1.677=29
\end{aligned}
$$

The sample size of this study was 40 . 


\section{Brand Image and Supply Chain Performance of Automobile Marketing Firms in Rivers State of Nigeria}

\section{MODEL SPECIFICATION}

This segment stipulates the following model that directed the study:

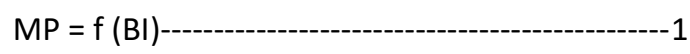

Where:

$\mathrm{SP}=$ Supply Chain Performance

$\mathrm{BI}=$ Brand Image

Therefore,

$$
M P=f(B I)
$$

The above equation is trans- customized into econometric form by adding constant term ( $\beta$ ) and error term (E) in the model below:

$$
\begin{aligned}
& S C P=f(B I) \\
& S C P=\beta 0+\beta B I+e------------------------1 \\
& S C P=\beta 0+\beta B I+e---------
\end{aligned}
$$

Mathematical form of the model is:

$$
S C P=\beta 0+\beta B I
$$

Where:

$\mathrm{SCP}=$ Supply Chain Performance

$\mathrm{BI}=$ Brand Image

$\beta 0=$ Intercept

$\beta 1=$ Coefficient of the predictor variable

$\mathrm{e}=$ error ter

\section{ANALYSIS OF RESEARCH QUESTIONS}

The descriptive relationships between the components of brand image and supply chainperformance are presented in relation to the research questions earlier stated in this study. Research questions one and two are combined in Table 1 . The essence of this is to ascertain the extent of the interaction of the components of brand image (brand identity and brand personality) with supply chain performance. The Pearson's Product Moment Correlation (PPMC) modus operandi was assumed for the research questions in order to explain the extent of the relationships between brand identity and brand personality with supply chain performance. Correlation point in the direction of the degree of linear association between two variables. The association was investigated by testing the significance between brand image components (brand identity and brand personality) and supply chain performance.

Table 1. Correlation Analysis showing the direction and strength of the extent of the relationship between brand image components and supply chain performance

\begin{tabular}{|l|l|l|}
\hline Correlations \\
\hline Variables & Pearson Correlation & P value (sig.) \\
\hline Brand Identity & $.766^{\mathrm{xx}}$ & 0.000 \\
\hline$* *$ Correlation significant at the 0.01 levels (2-tailed).
\end{tabular}

The correlation coefficient between supply chain performance and brand identity was found to be 0.766 at a $P<0.01$ level, and the correlation coefficient between supply chain performance and brand personality was found to be 0.442 at a $\mathrm{P}<0.01$ level. Therefore, it can be concluded that the extent of the relationship between brand identity and supply chain performance is strong, positive and significant, while the extent of the relationship between brand personality and supply chain performance is moderate, positive and significant. This shows that, firms putting into practice a well-organized brand image programs are inclined to have positive supply chain performance. 


\section{Brand Image and Supply Chain Performance of Automobile Marketing Firms in Rivers State of Nigeria}

\section{STATISTICAL TEST OF HYPOTHESES}

\section{Decision Rule}

Significant/probability value $(\mathrm{Pv})<0.05$ (level of significance $=$ conclude significant influence.

Significant probability value $(\mathrm{Pv})>0.05$ (level of significant = conclude insignificant influence.

\section{Test of Hypotheses One}

Ho1: Brand identity does not significantly influence supply chain performance.

$\mathbf{H}_{1}$ : Brand identity significantly influences supply chain performance.

The result of the regression analysis is presented in Table 2

Table 2. Summary of Regression Model for Brand Identity and Supply Chain Performance

\begin{tabular}{|l|l|l|l|}
\hline Model R & R square & Adjusted Square & R std error of the Estimate \\
\hline $1.766^{\text {a }}$ & .587 & .585 & 2.104 \\
\hline
\end{tabular} a. Predictors: (Constant), Brand Identity
b. Dependent Variable: Supply Chain Performance
Source: SPSS Window Output, Version 22.0 (based on 2022 field survey data).

The sum of supply chain performance was regressed with the sum of brand identity to examine the influence of brand identity on supply chain performance. The value of $\mathrm{R}$ is 0.766 . The $\mathrm{R}$ (coefficient of correlation) value of 0.766 represents the correlation between brand image and supply chain performance. It represents a strong correlation between the two variables. The $\mathrm{R}^{2}$ (coefficient of determination) which indicates the explanatory power of the independent variable is 0.587 . This means that $59 \%$ of the variation in supply chain performance is explained by the independent variable. It shows that brand identity makes a contribution of $59 \%$ to every change in supply chain performance. The $\mathrm{R}^{2}$ value as revealed by the result is moderate which means that about $0.41 \%$ of the variation in the dependent variable is unexplained by the model, denoting a moderate relationship between the explanatory variable, brand identity and supply chain performance.

\section{Test of Hypotheses Two}

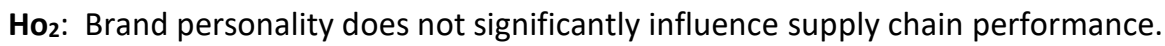

$\mathbf{H}_{2}$ : Brand personality significantly influences supply chain performance.

The result of the regression analysis is presented in Table 3

Table 3. Summary of Regression Model for Brand Personality and Supply Chain Performance

\begin{tabular}{|l|l|l|}
\hline R square & Adjusted Square & R std error of theEstimate \\
\hline .195 & .191 & 3.576 \\
\hline
\end{tabular}

a. Predictors: (Constant), Brand Personality

b. b. Dependent Variable: Supply chain performance

Source: SPSS Window Output, Version 22.0 (based on 2022 field survey data).

Sum of Supply chain performance was regressed with the sum of brand personality to examine the influence of brand personality on supply chain performance. The value of $R$ is 0.442 . The $R$ (coefficient of correlation) value of 0.442 represents the correlation between brand personality and Supply chain performance It represents a moderate correlation between the two variables. The $\mathrm{R}^{2}$ (coefficient of determination) which indicates the explanatory power of the independent variable is 0.195 . This means that $19 \%$ of the variation in supply chain performance is explained by the independent variable. It shows that brand personality makes a contribution of $19 \%$ to every change in supply chain performance. The $\mathrm{R}^{2}$ value as revealed by the result is quite low which means that about $0.81 \%$ of the variation in the dependent variable is unexplained by the model, denoting a moderate relationship between the explanatory variable, brand personality and supply chain performance.

\section{DISCUSSIONS OF FINDINGS}

It is clear as crystal that brand image is a substantial dynamic that propels supply chain performance, for the reason that it is a significant as indicator that boosts supply chain performance. A very fundamental step in guaranteeing supply chain 


\section{Brand Image and Supply Chain Performance of Automobile Marketing Firms in Rivers State of Nigeria}

performance is to understand brand image arrangements and embarks upon it appropriately. As divulged by the study's findings, brand image has significant influence on supply chain performance.

As a result, the first hypothesis declared in the null form, was statistically tested and rejected, and the alternative hypothesis that there is a significant influence of brand identity on supply chain performance was accepted. The concept of brand image as calculated in this study fingers issues projecting brand image as a positive driver of marketing performance. It becomes explicable that brand image makes Supply chain performance resourceful and thus capable of transmitting persistent outcomes. From the study's findings, it could be apprehended that when brand identity is correctly harmonized and assertively absorbed, it rubs down on supply chain performance. The study's finding is in line with the findings of Ibok and Etuk (2015) who established a strong positive and significant relationship between brand identity and customer loyalty and, Eduardo de Paula eSilva Chaves (2017) who revealed a significant association between brand identity, positioning, brand image and brand equity.

The second hypothesis affirmed that there is no significant influence brand personality on supply chain performance, but the study's finding confirms a moderate, positive and significant influence of brand personality on marketing performance. The significant result illustrates that brand personality could be a critical concept which business require to consider while crafting their supply chain performance programs. If companies take advantage of the positive effect of brand personality toward supply chain marketing performance, they will definitely achieve optimal supply chain performance. Thus, knowledge of the positive impact of brand personality on supply chain performance should be determinedly measured and mirrored by all stakeholders in the automobile marketing industry. Our research finding supports the findings of Ogbuji (2016) who discovered that brand personality strongly and positively associates with supply chain performance of deposit money banks in Port Harcourt. Our finding also corroborates Bouhlet (2011) discovery that brand personality influences customer loyalty and attachment as well as commitment for sincere and competent brand.

\section{CONCLUSION}

This work focused on investigating the influence of brand image on supply chain performance of automobile marketing firms in Rivers State. It is clear from the findings of the study that there is implied influence of brand image components (brand identity and brand personality) on supply chain performance, as the outcome of the statistical analysis reveals that brand identity has a strong, positive and significant influence on supply chain performance, and brand personality has a moderate, positive and significant influence on supply chain performance. Therefore, the study concludes that brand image significantly influences supply chain performance of automobile marketing firms in Rivers State, and recommends that, managers of automobile marketing firms should design brand image enhancing programs that are competent in bringing about positive supply chain performance in order to survive in the highly competitive and dynamic business landscape.

\section{REFERENCES}

1) .Aaker, J. L. (1997). Dimensions of brand personality. Journal of Marketing Research, 347-356.

2) Asim , N., Syed, K., Hussani, Emadul, K. \& Mohammad, Q.S. (2012) Analysis of influential factors on consumer buying behavior of youngster towards branded products: evidence from Karachi: KASBIT Business Journal, 5:56-61.

3) Azoulay, A. \& Kapferer, .J.N (2003). Do brand personality scale really measure brand personality? Brand Management,2(2), 143-155.

4) Bambong, S. \& Wajaya, S. (2015). Guests' waiting experience at hotels: Evidence from Saudi Arabia (2015). Thesis. Rochester Institute of Technology Retrieved on 13/03/2020.

5) Eduardo de Paula e Silva Chaves (2017). Identity, positioning, brand image and brand equity comparison: A vision about quality in brand management. Independent Journal of Management \& Production (IJM\&P), 8(4), $1246-1263$.

6) Freling, T. H. \& Forbes, L. P. (2005). An empirical analysis of the brand personality effect. Journal of Product \& Brand Management, 14(7), 404-413.

7) Gouteron, J. (2008). The impact of personality of the brand on the brand relationship in the field of mobile telephony, The Journal of Management Sciences, 233( 4), 115-27,

8) Harcourt, H. \& Ikegwuru, M, K. (2018). Analyzing the impact of brand loyalty on market performance: A study of food and beverage firms in Rivers State. Journal of Business and African Economy, 4(1), 1-14.

9) Ibok, N. \& Etuk, S. G. (2015). Brand identity and customers loyalty: Evidence from the Nigeria Telecommunication Industry. International Journal of Managerial Studies and Research (IJMSR),3(6), 1-8. 


\section{Brand Image and Supply Chain Performance of Automobile Marketing Firms in Rivers State of Nigeria}

10) Kamran, K. \& Farzaneh, K. (2017). Analyzing the effect of consumers' perception of brand personality on purchase intention (Case study: Maz Maz Company). International Journal of Humanities and Cultural Studies, 4(3), $161-172$.

11) Koll, O. \& von Wallpach, S. (2014). Intended brand associations: Do they really drive consumer response? Journal of Business Research, 67(7), 1501-1507.

12) Kotler, P. \& Armstrong, G. (2008). Principle of Marketing. New Jersey: Pearson Education.

13) Maclayton D.W. \& Nwokah, N.G. (2012). Measuring Business Excellence. Journal of Marketing 10(4),65-76.

14) McCormack, J. P. \& Cogan, J. (2004). Capturing, understanding and exploring brand identity with shape grammars. Elsevier Ltd., Design Studies, 25(1),1- 29.

15) Muhammad, I.T. Muhammad, R. N., Muhammad, M. Nawaz, N. G. (2012). Do brand personalities make a difference to consumers? Procedia-Social and Behavioral Sciences, 37, 31-37.

16) Ogbuji, C. N., Onuoha, A. O. \& Owhorchukwu, O. (2016). Brand personality and marketing performance of

17) deposit money banks in Port Harcourt, Nigeria. International Journal of Research in Business Studies and Management, 3(5), 37- 48.

18) Okpara, G. S. (2012). Contemporary Marketing: Topical and Topicalised, (2nd ed). Owerri: Avan Global Publications. 